\section{Commentary: The Ross Registry: Shedding new light on a historic procedure}

\author{
Sumner E. Kilmarx, AB, ${ }^{a}$ and Leora B. Balsam, $\mathrm{MD}^{\mathrm{b}}$
}

Since its first description in 1967 by Dr Donald Ross, the Ross procedure has found a small niche in the treatment armamentarium for aortic valve disease, resulting in improved quality of life for patients around the world. ${ }^{1-4}$ The major benefit for young patients undergoing the Ross procedure is the opportunity to achieve good long-term survival without the need for lifelong anticoagulation. However, it is no secret that the Ross procedure suffers from certain disadvantages that impact its broader use. Expertise is not uniform across centers; in fact, most adult cardiac surgeons have not been trained to perform this highly complex procedure. In addition, the need for reoperation after the Ross procedure, both in the right ventricular outflow tract and aortic root, has contributed to waxing and waning of enthusiasm for this procedure over the years. Importantly, there are alternative, well-accepted surgical therapies for advanced aortic valve pathology that are much more generalizable (specifically, aortic valve replacement [AVR] with a prosthetic valve). These factors contribute to the limited data regarding outcomes after the Ross procedure and have made it difficult for the procedure to find a larger foothold in the field of cardiac surgery. In this issue of the Jour$n a l$, Fujita and colleagues ${ }^{5}$ describe efforts to unify data from patients undergoing the Ross procedure into a largescale registry to allow more rigorous scientific evaluation of the technique.

The Ross Registry includes data from 12 European centers on nearly 3000 patients who have undergone the Ross procedure since 1988. While most of the enrolled patients

\footnotetext{
From the ${ }^{\mathrm{a}}$ University of Massachusetts School of Medicine; and ${ }^{\mathrm{b}}$ Division of Cardiac Surgery, UMass Memorial Medical Center, Worcester, Mass.

Disclosures: The authors reported no conflicts of interest.

The Journal policy requires editors and reviewers to disclose conflicts of interest and to decline handling or reviewing manuscripts for which they may have a conflict of interest. The editors and reviewers of this article have no conflicts of interest.

Received for publication July 29, 2021; revisions received July 29, 2021; accepted for publication July 30, 2021; available ahead of print Aug 5, 2021.

Address for reprints: Leora B. Balsam, MD, Division of Cardiac Surgery, UMass Memorial Medical Center, University Campus, 55 Lake Ave North, Worcester, MA 01655 (E-mail: leora.balsam@umassmemorial.org).

JTCVS Techniques 2021;10:401-2

2666-2507

Copyright (c) 2021 The Author(s). Published by Elsevier Inc. on behalf of The American Association for Thoracic Surgery. This is an open access article under the CC BY-NC-ND license (http://creativecommons.org/licenses/by-nc-nd/4.0/)

https://doi.org/10.1016/j.xjtc.2021.07.027
}

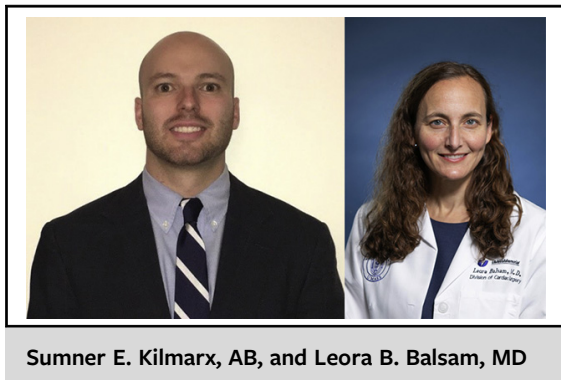

CENTRAL MESSAGE

The Ross Registry is a multicenter repository that may help cardiac surgeons better understand the relative strengths and weaknesses of this infrequent procedure.

are adults, there are more than 350 pediatric patients included in the registry. The purpose of the registry is to facilitate critical evaluation of outcomes after the Ross procedure. It has been leveraged, for example, to evaluate how modifications in surgical technique have impacted failure modes that can occur over time. The authors discuss the limitations of the single-arm Ross Registry; most importantly, it can only provide aggregate data that can be indirectly compared with outcomes after conventional AVR. It is unlikely that a large-scale, randomized-controlled trial comparing outcomes after the Ross procedure versus conventional AVR will ever occur. To date, only 2 such studies have been conducted, with significant limitations. One was a single-center trial comparing aortic root replacement with homografts versus pulmonary autografts ${ }^{6}$; the other was a small, single-center trial comparing outcomes after the Ross procedure versus mechanical AVR for aortic stenosis. ${ }^{7}$

While Fujita and colleagues ${ }^{5}$ provide a refreshing look at an undeniably fascinating technique, the Ross registry is unable to answer how, if at all, this approach is superior to conventional AVR. For now, the decision to offer the Ross procedure or conventional AVR is highly nuanced, involving provider preference and access to a surgeon with this specialized expertise. Will the Ross registry help bring a classic procedure out of the history books and into the operating room? Only time will tell.

\section{References}

1. Ross DN. Replacement of the aortic and mitral valves with a pulmonary autograft Lancet. 1967;2:956. 
2. Etnel JRG, Grashuis P, Huygens SA, Pekbay B, Papageorgiou G, Helbing WA, et al. The Ross procedure: a systematic review, meta-analysis, and microsimulation. Circ Cardiovasc Qual Outcomes. 2018;11:e004748.

3. Kouchoukos NT, Masetti P, Nickerson NJ, Castner CF, Shannon WD, DávilaRomán VG. The Ross procedure: long-term clinical and echocardiographic follow-up. Ann Thorac Surg. 2004;78:773-81.

4. Somerville J. The origins of the Ross operation. Images Paediatr Cardiol. 2012; $14: 3-5$
5. Fujita B, Aboud A, Sievers HH, Ensminger S. State-of-the-art: insights from the Ross registry. J Thorac Cardiovasc Surg Tech. 2021;10:396-400.

6. El-Hamamsy I, Eryigit Z, Stevens L-M, Sarang Z, George R, Clark L, et al. Longterm outcomes after autograft versus homograft aortic root replacement in adults with aortic valve disease: a randomised controlled trial. Lancet. 2010;376:524-31. 7. Doss M, Wood JP, Martens S, Wimmer-Greinecker G, Moritz A. Do pulmonary autografts provide better outcomes than mechanical valves? A prospective randomized trial. Ann Thorac Surg. 2005;80:2194-8. 